\title{
ROMANCE AND REALITY IN MISSIONARY WORK
}

\section{FIFTY YEARS OF THE GHINA INLAND MISSION}

Ir sometimes seems that romance in missionary work is rapidly becoming a thing of the past. Western machinery and manufactures are invading the East and creating conditions that bear an uninteresting resemblance to the conditions of life in Europe and America. But to those to whom the adventures of the spirit are as thrilling as the discoveries of the pioneer and as inexhaustible as the varieties of human speech and custom, the Jubilee Story of the China Inland Mission ${ }^{1}$ which has just been published will appear a real romance. Mr. Broomhall tells the story of the mission in the simplest way, leaving the facts to make their own impression, and it is only as we open our minds to receive their full effect that we realize how strange and stirring and significant the narrative is.

In the long and varied history of missions, the China Inland Mission occupies a place of its own. When it is compared with other types of missionary effort, whether in earlier periods or at the present day, there is no difficulty in recognizing its distinctive features. The principles on which its work is based are few and simple. But by the firmness of its grasp of one or two vital truths it has made a priceless contribution to the whole missionary movement.

The student of missionary history will feel, as he reads Mr. Broomhall's volume, that the China Inland Mission has certain marked limitations. For example, it does not require of its missionaries a long and thorough intellectual

1 The Jubiles Story of the China Inlemd Miceion. By Marsball Broomball. London: Morgan Scott. 1915. 
preparation, believing that where the need of labourers is so great, "persons of moderate ability and limited attainments are not precluded from engaging in the work.' It should be noted, however, that this policy is combined with very great care in the selection of missionaries, candidates being tested by a residence of some months in the mission house in London and with a thorough system of language training in China. The policy is not due to a lack of appreciation of the responsibilities of missionary life, but has been deliberately adopted in view of the insufficiency of more highly equipped workers, and every care is taken to guard against its possible dangers. Again, the mission has scarcely entered the field of higher education, and is thereby deprived of opportunities which other missions possess of influencing the leaders of the new movements in China. Questions of ecclesiastical polity do not occupy a large place in its programme : it has found a satisfactory working solution of the difficulties arising from its interdenominational character, but it has not yet had time to show that its methods would be adequate for the immense task of building up a national Christian church in China. The greatest limitation of all, as it will appear to many, is that the mission has concerned itself very little with the problems of thought. Its missionaries, for the most part, have made no large and serious attempt to relate the realities of Christian faith and experience to the conclusions of natural and historical science which are widely accepted by educated men both in the West and in the East. Geographically the China Inland Mission has taken the whole of China on its heart, but of the total sum of China's rich and manifold life it has left a large and important part to others to win for Christ. It may be questioned whether a mission posse sing these limitations could succeed unaided in fully evangelizing a nonchristian land. But the China Inland Mission itself would be the last to make such a claim. It professes 
only to supplement other agencies. And within its own special sphere it has given so clear and striking an exhibition of certain principles touching the very heart of missionary work that the whole missionary movement owes to it a profound debt of gratitude. The story which Mr. Broomhall tells suggests that in two important respects the China Inland Mission has a notable and distinctive contribution to make to the missionary life of the Church.

In the first place, the China Inland Mission, as its name bears witness, was born out of a conviction that the Gospel is a treasure of such infinite worth that by all means and at all costs it must be brought within the reach of those who are without it. It was an overwhelming sense of the needs of the inland provinces of China, in which no Protestant missionaries were at work, that drove Mr. Hudson Taylor, after a long and agonizing struggle, to found the China Inland Mission. If the Church with its recognized agencies would not enter the unoccupied field, then the only course open was to found a new mission in the faith that God would bless an effort made to carry out His will. The aim of evangelizing the whole of China has from the beginning been the guiding star of the mission. The aim has been pursued in no haphazard fashion, but in accordance with a definite policy of gaining an entrance first in the capital of each unoccupied province, then in the chief prefectures, and thus downwards to the smaller towns and villages. This policy necessarily involved long and adventurous journeys into unknown territories. The first journey by a non-official traveller across China from east to west through Yunnan into Burma was made by Mr. McCarthy of the China Inland Mission. Another missionary, Mr. Cameron, traversed on foot seventeen out of the eighteen provinces and also explored Manchuria, Mongolia, Chinese Turkestan, Eastern Tibet, Burma, and Hainan. A British consular report presented to Parliament in $\mathbf{1 8 8 0}$ bore witness to the services rendered by the missionaries of the China Inland Mission scattered 
through the various provinces in accustoming the Chinese to the presence of foreigners.

The power which sent these men and women through the length and breadth of the land to face danger and hardship and suffering was the missionary passion. 'One thing and one only,' wrote Mr. Taylor, ' will carry men through all, and make and keep them successful: the love of Christ constraining and sustaining is the only adequate power.' In the lives of many of the missionaries we recognize the true authentic note of apostolic devotion; in Adam Dorward, for example, who for eight years directed his whole energies to obtaining an entrance into the violently anti-foreign province of Hunan, and who wrote with reference to the city of Changteh: 'I feel I would be willing to do almost anything that would be honouring to God, to undergo any hardship, if I could get a permanent footing in this city, and have the joy of seeing men and women turning to God.' Not a few of the missionaries have sealed their witness with their blood, and to-day when the heart of Europe is moved by the splendid heroism of its son', we cannot withhold a tribute from those who with a courage not less noble and without the sustaining force of a nation's resolve behind them have laid down their lives for the advancement of the unseen Kingdom of righteousness and love. Other missions in China have shared to the full in the same heroism and devotion. But they would all readily acknowledge that the China Inland Mission has rendered an inestimable service to the cause of China's evangelization in pointing the way to the occupation of the whole field; and that it has given signal expression to the true missionary desire which has characterized so many great missionaries-St. Paul, Francis Xavier, Henry Martyn, David Livingstone-to press on to the regions beyond and "to preach the Gospel not where Christ was already named.' The part played by the China Inland Mission in opening China to missionary effort is one of the great 
adventures of faith. The feelings of the mission as it looks back over the fifty years of its history must be not unlike those of Kipling's 'Explore: :

Yes, your 'Never-never country'-yes, your 'edge of cultivation'

And 'no sense in going further'-till I crossed the range to see.

God forgive me! No $I$ didn't. It's God's present to our nation.

Anybody might have found it but-His Whispar ane to Me!

The second outstanding characteristic of the China Inland Mission is a profound conviction that God may be trusted to provide fully for all the needs of the work which He bids men do. It has accepted in a literal sense the saying which bids us seek first the kingdom of God, in the confident assurance that everything we need will be added unto us. It is the practice of the mission not to make any direct appeal for funds even when it is in urgent need. This is sometimes regarded as primarily a question of method, and it is pointed out quite justly that faith in God may be as truly manifested in devoted and self-sacrificing efforts to obtain the needed funds and workers as in relying upon no means except prayer. It has also to be borne in mind that the China Inland Mission with its interdenominational constituency is in a quite different position from denominational missionary societies, which have a definite responsibility for bringing home to every member of the denomination his duty to take some share in the evangelization of the world. But a careful reader of Mr. Broomhall's volume will realize that the policy of the China Inland Mission is much more than a method: it is a far-reaching, instructive and fruitful principle.

This principle has saved the mission from anxious preoccupation with questions of ways and means, and enabled it to concentrate its energies without distraction on its spiritual aims. 'In the study of the Divine Word,' Mr. Hudson Taylor wrote, 'I learned that to obtain successful labourers, not elaborate appeals for help, but first, earnest prayer to God to thrust forth labourers, 
and second, the deepening of the spiritual life of the Church, so that men should be unable to stay at home, were what was needed.' The importance of the truth expressed in these words can hardly be exaggerated in view of the growing ascendancy which material things have assumed in modern times.

The same principle has made it possible for the mission to pursue unfalteringly its aim of evangelizing the whole of China. To quote Mr. Taylor again : 'I saw that the apostolic plan was not to raise ways and means but to go to do the work.' In 1881 the missionaries in China, after reviewing carefully the needs of the different provinces, reached the conclusion that seventy additional workers were immediately needed, and in spite of the fact that the funds at the time were lower than they had been for four years, resolved to issue an appeal for the reinforcements needed. The ground of their action was stated by Mr. Taylor in these words : "We feel that if God saw it needful to try our faith, He could do so whether we were seventy more or seventy less, and if $\mathrm{He}$ were pleased to supply us abundantly, the additional seventy would be no difficulty to Him.'

Again, Mr. Broomhall's pages furnish abundant evidence that this daring reliance upon God has been a fruitful spiritual discipline, compelling the mission to give itself continually to prayer and to learn the will of God regarding every step in its development.

The mission, though it has never solicited funds, has since its foundation fifty years ago received nearly

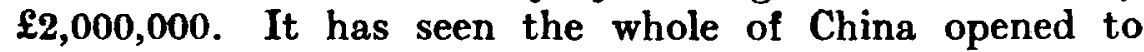
the Gospel. With its auxiliary agencies it has at present 1063 foreign missionaries at work in China. The extent of its operations may be gauged from the fact that $\mathrm{Mr}$. Broomhall, who has recently returned from a tour in China, tells us that it would require at least five years to visit personally all the main stations of the mission, while if the out-stations were also visited, another ten 
or even twenty years would be required. These bare facts are sufficiently remarkable. But to understand their real meaning it is necessary to read the story of the spiritual adventures, the testing of faith, the sufferings and patience, the unceasing and marvellous answers to prayer by which the results have been brought to pass.

One other illustration may be given of the way in which the mission has carried out the principle of pursuing its spiritual aims without regard to material considerations. The practice of the mission from the beginning has been not to accept any compensation for the destruction of life. In regard to property the mission has never claimed compensation, but has at different times accepted it when offered by the Chinese Government or claimed by a foreign Government on behalf of the mission. After the Boxer rising, however, the mission after earnest consideration resolved not to accept compensation for the destruction of property even if offered. The announcement of this decision led to the issue of a remarkable proclamation by the Governor of Shansi, which was posted in every centre where the mission had suffered. The proclamation after enunciating the Christian principle of love continued : ' Contrasting the way in which we have been treated by the missionaries with our treatment of them, how can any one who has the least regard for right and reason not feel ashamed of this behaviour. ... From this time forward I charge you all, gentry, scholars, army, and people, those of you who are fathers to exhort your sons, and those who are elder sons to exhort your younger brothers, to bear in mind the example of Pastor Hoste, who is able to forbear and to forgive as taught by Jesus to do.' Mr. Broomhall's comment on this incident is : 'This proclamation posted up throughout the province was an object lesson to all, and was calculated to do more to make known the spirit of Jesus Christ than many years of preaching, and from this standpoint alone was worth far more than any amount of compensation.' 
The principles to which the China Inland Mission has borne quiet, steadfast and impressive witness are of peculiar value at a time when the Christian Church with straitened resources and under conditions of greatly increased difficulty has to take up afresh the work which the war has interrupted. Their far-reaching importance has yet to be fully appreciated. The experiences of the mission are a rich storehouse from which the whole Church may draw inspiration and strength. Mr. Broomhall has rendered a great service to the missionary cause in giving us at the present crisis this wonderful story of the things that are possible to those who trust God with the simple faith of a little child.

J. H. Oldham 